\title{
Carbon isotope discrimination and yield in 14 cool-season grasses
}

\author{
DOUGLAS A. JOHNSON, KAY H. ASAY, AND KEVIN B. JENSEN
}

Authors are Plant Physiologist, Research Geneticist (retired), and Research Geneticist, USDA-ARS Forage and Range Research Lab., Utah State Univ., Logan, Ut. 84322-6300.

\begin{abstract}
Selection for carbon isotope discrimination $(\Delta)$ has potential for improving water-use efficiency in cool-season grasses. An understanding of how $\Delta$ is affected by differential water application and its association with dry mater yield may be helpful in identifying the best cool-season grass species for breeding and improvement, and may assist in designing selection and breeding procedures for improving cool-season grasses. We designed a study to evaluate the response of $\Delta$ and dry matter yield to a gradient of water application in 14 cool-season, perennial grasses. The grasses were established in a rainout shelter facility equipped with a line-source irrigation system to study the: i) trends in dry matter yield across 6 water levels (WL-1 through 6, ranging from 981 to $64 \mathrm{~mm}$ water applied) and $\Delta$ across 3 water levels (WL-1, 3, and 5), ii) grass $x$ water level interactions for these traits, and iii) relationship between dry matter yield and $\Delta$ in these grasses across a 2 -year period. When averaged across years, the grasses differed significantly for $\Delta$ at the highest (WL1) and lowest (WL-5) water levels, but not at WL-3. Reductions in $\Delta$ were strongly linear from WL-1 to WL-5, and although some inconsistencies were evident, the trend was similar for all grasses. Grasses differed significantly for dry matter yield at each of the water levels. Although the change in dry matter yield was mostly linear across water levels, the trend was not consistent among the grasses. In general, $\Delta$ was not closely associated with dry matter yield; however, some exceptions with high dry matter yield and high $\Delta$ were evident. This lack of close association between dry matter yield and $\Delta$ in these 14 grasses suggests that breeding efforts to improve these grasses should involve simultaneous selection for dry matter yield and $\Delta$.
\end{abstract}

Key Words: water-use efficiency, dry matter yield, line-source sprinkler system, rainout shelter, forage

The mechanisms plants use to respond to drought and the various screening methods that have been used to improve drought responses of forage grasses were reviewed by Asay and Johnson (1983) and Johnson and Asay (1993). Ideally, forage grasses should produce large amounts of high quality forage and at the same time make efficient use of limited water resources (wateruse efficiency, amount of carbon gained per unit of water tran-

We express our appreciation to Kevin Connors for his skilled technical assistance during all phases of this research. Published as Journal Paper No. 7417 of the Utah Agricultural Experiment Station at Utah State University, Logan, Ut. 84322-4810.

Manuscript accepted 16 Jan. 2003

\section{Resumen}

La selección por medio de la discriminación del isótopo de carbón $(\Delta)$ tiene el potencial para mejorar la eficiencia del uso del agua en zacates de estación fría. Un entendimiento de cómo $\Delta$ es afectado por la aplicación diferencial de agua y su asociación con el rendimiento de materia seca puede ser útil en identificar las mejores especies de estación fría para el mejoramiento genético y puede ayudar en diseñar procedimientos de selección y mejoramiento genético de estos zacates. Diseñamos un estudio para evaluar la respuesta de $\Delta$ y el rendimiento de materia seca a un gradiente de aplicación de agua en 14 zacates perennes de estación fría. Los zacates se establecieron en una instalación equipada con protector contra lluvia y con un sistema de irrigación de línea para estudiar: i) las tendencies en el rendimiento de material seca a través de 6 niveles de agua (WL-1 al 6, fluctuando de 981 a $64 \mathrm{~mm}$ de agua aplicada) y el $\Delta$ en tres niveles de agua (WL-1, 3, y 5), ii) interacciones entre zacate $x$ nivel de agua para estas características y iii) la relación entre la materia seca y $\Delta$ en estos zacates en un período de 2 años. Cuando se promedio a través de los años, los zacates defirieron significativamente respecto a $\Delta$ en el nivel más alto (WL-1) y más bajo (WL-5) de agua, pero no hubo diferencia en el nivel WL-3. Las reducciones en $\Delta$ fueron lineales de WL-1 a WL-5, y aunque algunas inconsistencias fueron evidentes, la tendencia fue similar para todos los zacates. Las especies de zacate difirieron significativamente en cuanto a rendimiento de materia seca en cada uno de los niveles de agua. Aunque el cambio en la materia seca fue principalmente lineal a través de los niveles de agua, la tendencia no fue consistente entre las especies. En general, $\Delta$ no estuvo estrechamente correlacionado con el rendimiento de material seca, sin embargo, algunas excepciones con alta material seca y alto $\Delta$ fueron evidentes. Esta falta de una asociación estrecha entre el rendimiento de materia seca y _ en estos 14 zacates sugiere que los esfuerzos de mejoramiento genético para mejoralos debe involucrar la selección simultanea para el rendimiento de materia seca y $\Delta$.

spired). Because of the overriding influence of limited water on plant growth, screening procedures used in breeding programs for rangeland and pasture plants in the western U.S. must be able to identify breeding lines that combine superior productivity with high water-use efficiency.

Finding appropriate screening techniques to assess water-use efficiency has proven extremely challenging, and a lack of effec- 
tive screening procedures has impeded progress in evaluating plants for water-use efficiency. Although direct measurements of aboveground dry matter can be routinely assessed in field evaluations, accurate determinations of root dry mass and the amount of water transpired for each plant, which are required to calculate water-use efficiency, are impractical to obtain in most breeding programs. These challenges are compounded because of the many breeding lines that must be evaluated in typical plant improvement programs. In addition, measurements of transpiration rate, photosynthetic activity, and other traits associated with plant gas exchange or water relations represent instantaneous characterizations that may not reflect integrated responses across the multiple stages of plant development.

Farquhar et al. (1982) developed the theoretical basis for the relationship between carbon isotope discrimination $(\Delta)$ and leaf intercellular $\mathrm{CO}_{2}$ concentration, which is associated with water-use efficiency. This theory suggests a negative association between $\Delta$ and water-use efficiency, which was first documented in wheat (Triticum aestivum L.) (Farquhar and Richards 1984, Condon et al. 1990). Since then, a negative relationship between $\Delta$ and water-use efficiency has been reported in a wide range of $\mathrm{C}_{3}$ species (Brugnoli and Farquhar 2000), which includes the following cool-season grasses: crested wheatgrass (Agropyron desertorum (Fisch. ex Link) Schultes) (Read et al. 1991, Johnson et al. 1990); Altai wildrye (Leymus angustus (Trin.) Pilger) (Johnson et al. 1990); and orchardgrass (Dactylis glomerata L.), tall fescue (Festuca arundinaceae Schreb.), and perennial ryegrass (Lolium perenne L.) (Johnson and Bassett 1991). Based on theory and these documented relationships, $\Delta$ has been suggested as a means to improve water-use efficiency in $\mathrm{C}_{3}$ crop species (Farquhar and Richards 1984) and in perennial, cool-season grasses (Johnson et al. 1990, Johnson and Bassett 1991, Asay et al. 1998). Because $C$ is continually being assimilated through photosynthesis, $\Delta$ offers potential in integrating water-use efficiency responses across the growing season, which suggests that $\Delta$ may be more useful than most instantaneous physiological measurements for selection. Research related to $\Delta$ and plant breeding was reviewed by Hall et al. (1994).

The present study was designed to determine the response of $\Delta$ and dry matter yield to a gradient of water application in 14 perennial, cool-season forage grasses; examine the grass $\mathrm{x}$ water level interaction for $\Delta$ and dry matter yield; and evaluate the relationship of $\Delta$ to dry matter yield in these grasses. Establishing these relationships in a broader spectrum of cool-season grasses may contribute to a better understanding of the interaction between $\Delta$ and dry matter as affected by water. They also may be helpful in identifying the best cool-season grass species for breeding and improvement, and assist in designing selection and breeding procedures for improving water-use efficiency and dry matter yield in a broader scope of grass species and hybrids.

\section{Materials and Methods}

\section{Plant Materials}

The following 14 experimental breeding lines and cultivars of important cool-season, perennial grasses were included in the study: 'Hycrest' crested wheatgrass [Agropyron cristatum (L.) Gaertn. x A. desertorum; a breeding line of hexaploid $(2 \mathrm{n}=6 \mathrm{x}=42)$ crested wheatgrass $(A$. cristatum); a breeding line (designated AI Hybrid) and 'Greenar' intermediate wheatgrass [Thinopyrum intermedium (Host) Barkworth \& D.R. Dewey]; 'Alkar' tall wheatgrass [T. ponticum (Podp.) Barkworth \& D. R. Dewey]; 'Prairieland' Altai wildrye; a breeding line of Leymus karelinii (Turcz) Tzvelev; 'Magnar' Great Basin wildrye [L. cinereus (Scribn. \& Merr.) A. Löve]; a breeding line of a trihybrid involving Great Basin wildrye, Altai wildrye, and mammoth wildrye $[L$. racemosus (Lam.) Tzvelev] designated as Leymus hybrid; a natural hybrid between bluebunch wheatgrass [Pseudoroegneria spicata (Pursh) A. Löve] and crested wheatgrass designated as bluebunch wheatgrass hybrid; the cultivar 'NewHy' and a breeding line (RS-H) of the RS hybrid (Elymus hoffmannii Jensen \& Asay); 'Manchar' smooth bromegrass (Bromus inermis Leyss); and 'Kay' orchardgrass. These various breeding lines and cultivars will be referred to hereafter as grasses.

\section{Experimental Design}

The study was conducted in a rainout shelter (10-m by $47-\mathrm{m}$ plot area) modified after Upchurch et al. (1983), located at the Utah State University Evans Experimental Farm, approximately $2 \mathrm{~km}$ south of Logan, Utah $\left(41^{\circ} 45^{\prime} \mathrm{N}, 111^{\circ} 48^{\prime} \mathrm{W}, 1,350\right.$ $\mathrm{m}$ above sea level). Soil at the study site is a Nibley silty clay loam series (fine, mixed, mesic Aquic Argiustoll). Plots of the individual grasses were established perpendicular to a line-source sprinkler in 3 rows of 14 plants with each plant being $30-\mathrm{cm}$ away from its 4 neighboring plants. Single plants on the end of each row were designated as border plants. The remaining 36 plants ( 3 rows x 12 plants) were divided into 6 water levels, each consisting of 6 plants ( 3 rows $x 2$ plants). Plots receiving the most irrigation (WL-1) were located adjacent to the irrigation pipe, and plots receiving the least irrigation (WL-6) were the most distant from the irrigation pipe. The experiment was arranged as a modified split-plot design with the 14 grasses as whole plots and the 6 water levels as subplots. Whole plots were randomized in 4 blocks (replications), 2 on each side of the line-source irrigation pipe. The rainout shelter closed to cover the plots during most periods of precipitation and remained open at all other times. As a result, water received by the plots was restricted to that applied by the line-source irrigation system, except for some snow that was allowed to fall on the plot area during the winter.

Grass seeds were germinated in blotter trays, germinating seeds were transplanted into super-cell plastic cone-tainers $(22 \mathrm{~cm}$ deep, $4 \mathrm{~cm}$ diam.) that contained 3:1 soil/peat (different than the soil in the rainout shelter), and plants were placed in a greenhouse. Seedlings were transplanted into field plots on 19 September 1991, and plots were watered uniformly as needed during that autumn for establishment. Irrigation treatments were initiated the first week of May and continued through October during 1992 and 1993 to establish the water gradient and during the following 2 years of data collection. Water application received in the study plots was measured with plastic rain gauges placed in each of the 6 water application treatments in each of the 4 replications of the experiment. Average amounts of water received by the 6 plots from May through October in 1994 and 1995 were 981,916 , $733,465,155$, and $64 \mathrm{~mm}$ for WL-1 through WL-6, respectively. Individual water application amounts for 1994 were $846,801,640,369,156$, and $96 \mathrm{~mm}$ for WL-1 through WL-6, respectively. Corresponding amounts in 1995 were $1,116,1,030,825,560,153$, and $32 \mathrm{~mm}$, respectively. Amounts of water application differed between the 2 years because of differing evapotranspiration demands and the associated amounts of water required to maintain the gradient of plant growth from the highest to the lowest water application levels. All plots received 
$85 \mathrm{~kg} \mathrm{~N}, \mathrm{P}$, and $\mathrm{K} \mathrm{ha}^{-1}$ during mid-winter when the soil was frozen.

\section{Data Collection}

Plots were harvested at an $8-\mathrm{cm}$ stubble height on 13-14 July during 1994 and 1995, which was after all grasses had flowered. An $8-\mathrm{cm}$ stubble height was used because this represents an average height for cutting and/or grazing for the wide range of grasses evaluated in our study. A second harvest was made on 8-9 November in 1994 and 14-15 November in 1995. Dry matter yield (expressed as $\mathrm{Mg} \mathrm{ha}^{-1}$ ) was determined for the 2 harvest dates and 6 water levels in each year of data collection by drying the clipped forage at $60^{\circ} \mathrm{C}$ to a constant weight. For determinations of $\Delta$, flag leaves were sampled from each plant at the first harvest of each year of data collection for WL-1, WL-3, and WL-5. The number of flag leaves harvested for each species within each water level varied from about 12 to 60 leaves because of the variation in flag leaf mass among the 14 grasses at their respective water levels. A minimum of 1 gram of ground, dried leaf material was required for the determination of $\Delta$. Leaf samples were dried in a forced-air oven at $60^{\circ} \mathrm{C}$ and ground to pass through a $0.7-\mathrm{mm}$ mesh screen and then combusted in a $\mathrm{C}$ and $\mathrm{N}$ analyzer (Carlo Erba NA1500; Fisons Instruments, Valencia, California). The $\mathrm{CO}_{2}$ and $\mathrm{N}_{2}$ gases were separated at $50^{\circ} \mathrm{C}$ on a chromatographic column monitored by a thermal conductivity detector, and each peak was integrated for determination of percent $\mathrm{N}$ and $\mathrm{C}$. The $\mathrm{CO}_{2}$ gas was then transferred into a trapping system, cryogenically purified, and analyzed for $\delta^{13} \mathrm{C}\left({ }^{13} \mathrm{C} /{ }^{12} \mathrm{C}\right.$ ratio relative to that of the Pee Dee belemnite (PDB) standard) using an isotope ratioing mass spectrometer (SIRA 10; Fisons Instruments). Precision for $\delta^{13} \mathrm{C}$ was better than $0.1 \%$ o (per mil). Standards 21 and 22 (NIST) were used routinely to verify values of the working standards. The $\delta^{13} \mathrm{C}$ values were converted to $\Delta$ as described by Farquhar et al. (1989), assuming that the $\delta^{13} \mathrm{C}$ of air on the site was $-8 \%$ on the PDB scale (Mook et al. 1983).

\section{Statistical Analysis}

Total dry matter yield and $\Delta$ were analyzed within and across grasses and years using the GLM procedure (SAS Institute Inc. 1999). Because the line-source sprinkler system does not allow water levels to be randomized within grasses, mean squares for grass, water level, and the grass $\mathrm{x}$ water level interaction were tested with their first-order interactions with replications. Statistical analyses were made at 6 water levels for dry matter yield and at 3 water levels for $\Delta$. Data from individual years were treated as repeated measures in the analyses of data combined across years. Mean separations were made on the basis of the Fisher's protected least significant difference (LSD) at the 0.05 level of probability. Linear, quadratic, and cubic trends of dry matter yield and $\Delta$ across water level were determined for each grass using orthogonal polynomials with unequal intervals (Gomez and Gomez 1984). The slopes of linear regressions were also computed within each grass across water levels. The amount of water received at each water level was used in the computation of regression slopes and the coefficients used in the analyses of linear trends using orthogonal polynomials. This was done because the water applied was not linear across water levels.

\section{Results}

\section{Carbon Isotope Discrimination}

Grasses differed significantly $(\mathrm{P}<0.01)$ for carbon isotope discrimination $(\Delta)$ in the analyses of data combined across the 3 water levels for each year and also when data were analyzed across years (Table 1). In the analysis of $\Delta$ values within water levels, grasses differed significantly $(\mathrm{P}<$ 0.01 ) at WL-1 and WL-5 in 1994, at WL-1 $(\mathrm{P}<0.01)$ and WL-3 $(\mathrm{P}<0.05)$ in 1995 , and at WL-1 and WL-5 in the analysis combined across years. The variation

Table 1. Mean squares from ANOVA for carbon isotope discrimination $(\Delta)$ of 14 perennial, coolseason grasses at 3 water levels (WL) and combined across water levels, for each year separately and combined across 2 years.

\begin{tabular}{|c|c|c|c|c|c|}
\hline \multirow[b]{2}{*}{ Source } & \multicolumn{5}{|c|}{ Carbon isotope discrimination $(\Delta)$} \\
\hline & df & WL-1 & WL-3 & WL-5 & Combined \\
\hline & & --------- & - & & 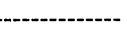 \\
\hline \multicolumn{6}{|l|}{1994} \\
\hline Grass & 13 & $0.88 * *$ & 0.73 & $1.47 * *$ & $2.31^{* *}$ \\
\hline Water level (WL) & 2 & ----- & ---- & ---- & $51.77 * *$ \\
\hline Grass x WL & 26 & ---- & ----- & $-\cdots$ & 0.39 \\
\hline \multicolumn{6}{|l|}{1995} \\
\hline Grass & 13 & $0.71 * *$ & $0.58^{*}$ & 1.58 & $1.92 * *$ \\
\hline Water level (WL) & 2 & ----- & ---- & ----- & $98.95 * *$ \\
\hline Grass x WL & 26 & $-\cdots$ & ---- & ---- & 0.47 \\
\hline \multicolumn{6}{|l|}{ Combined } \\
\hline Grass & 13 & $1.27 * *$ & 0.67 & $2.55^{* *}$ & $3.30 * *$ \\
\hline Water level (WL) & 2 & ----- & -..-- & ---- & $142.68 * *$ \\
\hline Grass x WL & 26 & ----- & ---- & ----- & 0.59 \\
\hline Year & 1 & $88.70 * *$ & $102.05 * *$ & $34.87 * *$ & $208.31 *$ \\
\hline Grass x Year & 13 & 0.32 & $0.64 *$ & 0.41 & $0.74 * *$ \\
\hline WL x Year & 2 & ----- & ----- & ----- & $4.21 * *$ \\
\hline Grass x WL x Year & 26 & ----- & ----- & ----- & 0.27 \\
\hline
\end{tabular}

$*, * *$ Significant at 0.05 and 0.01 probability levels, respectively. among grasses as indicated by the range and standard deviation (SD) in $\Delta$ values was greatest at the driest water level, WL-5 (Table 2). When combined across years, the range and SD among $\Delta$ values were 1.8 and $0.56 \%$, respectively, for WL-5, which received an average of $155 \mathrm{~mm}$ of water from May through October. Corresponding values for the range and SD of $\Delta$ were 1.3 and $0.4 \%$ for WL-1 (981 mm water applied) and 0.9 and $0.29 \%$ for WL-3 (733 mm water applied), respectively. The mean slope (rate of change or $b$ value) of the regression between $\Delta$ and water levels across all the grasses was $0.27 \%$ o $\mathrm{dm}^{-1}$ water applied. Essentially all (99\%) of the differences due to water level were associated with linear effects, as determined by orthogonal contrasts. The mean $\Delta$ values were $20.0 \%$ o for WL-1, $19.6 \%$ for WL-3, and $17.8 \%$ or WL-5.

The grass $\mathrm{x}$ water level interaction $(\mathrm{G} \mathrm{x}$ WL) for $\Delta$ was not significant in either year (Table 1), indicating that the grasses were responding in a similar manner to changes in water levels. Although the consistency across water levels is generally supported by the uniformity of the regression slopes (b values) for the individual grasses across water levels, some divergence was apparent (Table 2). The regression slopes were relatively consistent among the grasses except for the hexaploid crested wheatgrass strain $(b=0.42)$ and Leymus karelinii $(\mathrm{b}=0.18)$ (Table 2). The decrease in $\Delta$ values was considerably greater with reduced water for hexaploid crested wheatgrass than the other 
Table 2. Means and trends in carbon isotope discrimination $(\Delta)$ and total dry matter yield of 14 perennial, cool-season grasses at individual water levels (WL), combined across 2 years. Total dry matter yield was determined from combined individual harvests in July and November of 1994 and $1995(n=8)$.

\begin{tabular}{|c|c|c|c|c|c|c|c|c|c|c|}
\hline & \multicolumn{4}{|c|}{$\Delta$} & \multirow[b]{2}{*}{ Lin. $^{2}$} & \multicolumn{5}{|c|}{ Dry matter yield } \\
\hline & WL-1 & WL-3 & WL-5 & $b^{1}$ & & WL-1 & WL-3 & WL-5 & $\mathrm{b}$ & Lin \\
\hline & \multicolumn{4}{|c|}{ - } & $(\%)$ & \multicolumn{3}{|c|}{$\left(\mathrm{Mg} \mathrm{ha}^{-1}\right)$} & & (\%) \\
\hline Hycrest crested $\mathrm{WG}^{3}$ & 20.7 & 20.0 & 18.8 & 0.22 & 99 & 8.05 & 7.29 & 5.55 & 0.34 & 9 \\
\hline AI intermediate WG & 19.9 & 19.6 & 17.7 & 0.28 & 97 & 9.62 & 7.59 & 4.68 & 0.70 & 94 \\
\hline Greenar intermediate WG & 20.2 & 19.8 & 18.2 & 0.25 & 99 & 9.45 & 7.76 & 5.10 & 0.61 & 93 \\
\hline Alkar tall WG & 20.2 & 20.0 & 18.4 & 0.23 & 96 & 13.18 & 11.03 & 5.02 & 0.95 & 92 \\
\hline Magnar Basin wildrye & 19.4 & 19.2 & 17.3 & 0.27 & 96 & 3.82 & 2.90 & 4.24 & 0.14 & 19 \\
\hline Leymus hybrid & 19.7 & 19.6 & 17.6 & 0.27 & 95 & 10.34 & 7.45 & 4.27 & 0.78 & 96 \\
\hline Bluebunch WG hybrid & 19.9 & 19.4 & 17.1 & 0.35 & 98 & 5.29 & 3.78 & 3.67 & 0.29 & 75 \\
\hline NewHy RS hybrid & 19.7 & 19.5 & 17.5 & 0.27 & 95 & 6.19 & 6.03 & 3.12 & 0.58 & 86 \\
\hline RS-H RS hybrid & 19.7 & 19.5 & 17.8 & 0.24 & 96 & 7.61 & 6.25 & 2.81 & 0.69 & 93 \\
\hline Manchar smooth brome & 19.4 & 19.1 & 17.5 & 0.24 & 99 & 10.21 & 7.97 & 4.55 & 0.89 & 94 \\
\hline Kay orchardgrass & 19.8 & 19.3 & 17.7 & 0.27 & 100 & 6.92 & 5.79 & 0.58 & 0.79 & 99 \\
\hline
\end{tabular}

$\mathrm{T} b=$ regression coefficient of $\Delta$ and dry matter yield of entries across WL. Although only $3 \mathrm{WL}$ are reported here, 6 WL were used in determining the regression relationship. Values for WL (independent variable) expressed as $\mathrm{dm}$ of water received by plots.

${ }^{2} \mathrm{Lin}$. = Percent of WL sums of squares due to linear effects, based on orthogonal polynomials with unequal spacings.

${ }^{3} \mathrm{WG}=$ wheatgrass

${ }^{4} \mathrm{SD}=$ Standard deviation among entry means at each WL

grasses in our study, whereas those for $L$. karelinii exhibited the smallest change with decreasing water application. Within the different grasses, 95 to $100 \%$ of the variation due to water level was associated with linear effects. Some inconsistency in $\Delta$ across water levels is also indicated in the correlation matrix (Table 3). Although the correlations (r) among mean $\Delta$ values for the different water levels were significant $(\mathrm{P}<0.01)$ between WL-1 and WL-3 $(\mathrm{r}=0.67)$ and between WL-3 and WL-5 ( $\mathrm{r}$ $=0.88)$, the $\mathrm{r}$ value between WL-1 and WL-5 was not significant $(\mathrm{P}>0.05)$.

\section{Dry Matter Yield}

Grasses differed significantly $(P<0.01)$ for dry matter yield at all water levels in the analyses within years and in the analysis combined across years (Table 4). Relative differences among grasses were not consistent across water levels as indi-

Table 3. Pearson correlation coefficients ( $r$ ) for regressions of carbon isotope discrimination $(\Delta)$ and total dry matter yield in 14 perennial, cool-season grasses at 3 water levels (WL) across 2 years $(n=14)$.

\begin{tabular}{llllllll}
\hline \hline & & \multicolumn{2}{c}{$\Delta$} & & \multicolumn{3}{c}{ Dry matter yield } \\
\cline { 4 - 7 } \cline { 5 - 7 } & & WL-3 & WL-5 & & WL-1 & WL-3 & WL-5 \\
\hline$\Delta$ & WL-1 & $0.67^{* *}$ & 0.51 & 0.05 & 0.14 & 0.17 \\
& WL-3 & & $0.88^{* *}$ & 0.45 & $0.54^{*}$ & 0.44 \\
\multirow{3}{*}{ Dry matter yield } & WL-5 & & & 0.45 & $0.60^{*}$ & 0.41 \\
& WL-1 & & & & $0.92^{* *}$ & 0.46 \\
& WL-3 & & & & & 0.50 \\
& WL-5 & & & & & \\
\hline
\end{tabular}

*,** Significant at 0.05 and 0.01 levels of probability, respectively cated by the highly significant $(P<0.01)$ grass $\mathrm{x}$ water level interactions ( $\mathrm{G} \times \mathrm{WL}$ ) (Table 4). The correlation between WL-1 and WL-3 was positive and significant ( $\mathrm{r}$ $=0.92, \mathrm{P}<0.01)$ (Table 3). Dry matter yield increased from WL-5 to WL-1 in a significant and near linear manner (Table 2 ). The mean rate of change, as indicated by the regression slope (b value) of dry matter yield with water application, was $0.58 \mathrm{Mg} \mathrm{ha}^{-1}$ of dry matter $\mathrm{cm}^{-1}$ of water applied. In addition, $97 \%$ of the variation due to water levels was associated with linear effects in the analysis of data combined across grasses and years. Considerable variation was found among $b$ values indicating that dry matter yield of the grasses declined at different rates. For example, the $b$ value for the cultivar Alkar tall wheatgrass was 0.95 and for Manchar was 0.89 , indicating sharp declines of dry matter yield with decreasing water. In con- trast dry matter yield for Magnar Basin wildrye was only 0.14 , indicating a relatively uniform performance across water levels, but with a low dry matter yield at high available water (WL-1). These differences in response of grasses to water application were also a major factor contributing to the significant grass $\mathrm{x}$ water level interaction for dry matter yield.

\section{Relationship between Dry Matter Yield and $\Delta$}

There was a consistently positive, but relatively low, correlation between carbon isotope discrimination $(\Delta)$ and dry matter yield (Table 3 ). The $r$ values between the 2 traits were 0.05 for WL-1, $0.54(\mathrm{P}<0.05)$ for WL-3, and 0.41 for WL-5. The correlation between $\Delta$ at WL- 5 and dry matter yield at WL-3 also was significant $(\mathrm{r}=$ $0.60, \mathrm{P}<0.05$ ). Although these general associations across all grasses were not strong, some exceptions were evident. For example, $\Delta$ for Hycrest crested wheatgrass was significantly greater than $\Delta$ for the hexaploid crested wheatgrass at the driest water level (WL-5). However, Hycrest produced significantly more dry matter than the hexaploid crested wheatgrass at WL-5 and the other 2 levels as well. A similar relationship was observed for Hycrest and the bluebunch wheatgrass hybrid at WL-5. Perhaps most noteworthy is that dry matter yield for Hycrest was equivalent to or significantly greater than 
Table 4. Mean squares from ANOVA for total dry matter yield of 14 perennial, cool-season grasses at 3 water levels (WL) and combined across water levels, for each year separately and combined across 2 years.

\begin{tabular}{|c|c|c|c|c|c|}
\hline \multirow[b]{2}{*}{ Source } & \multicolumn{5}{|c|}{ Dry matter yield } \\
\hline & df & WL-1 & WL-3 & WL-5 & Combined \\
\hline & & ------------ & $(M$ & $-1)$ & \\
\hline \multicolumn{6}{|l|}{1994} \\
\hline Grass & 13 & $10.45 * *$ & $13.13 * *$ & $3.73 * *$ & $19.50 * *$ \\
\hline Water level (WL) & 5 & $\longrightarrow$ & - & - & $127.46 * *$ \\
\hline Grass x WL & 65 & $\longrightarrow$ & $\longrightarrow$ & - & $3.89 * *$ \\
\hline \multicolumn{6}{|l|}{$\underline{1995}$} \\
\hline Grass & 13 & $47.28 * *$ & $29.88 * *$ & $12.06 * *$ & $66.27 * *$ \\
\hline Water level (WL) & 5 & $\longrightarrow$ & $\longrightarrow$ & $\longrightarrow$ & $372.35^{* *}$ \\
\hline Grass $\mathrm{x}$ WL & 65 & $\longrightarrow$ & $\longrightarrow$ & $\longrightarrow$ & $2.58 * *$ \\
\hline \multicolumn{6}{|l|}{ Combined } \\
\hline Grass & 13 & $49.33 * *$ & $37.24 * *$ & $13.50 * *$ & $72.79 * *$ \\
\hline Water level (WL) & 5 & $\longrightarrow$ & $\longrightarrow$ & $\longrightarrow$ & $486.11^{* *}$ \\
\hline Grass $x$ WL & 65 & - & {[} & $\longrightarrow$ & $13.24 * *$ \\
\hline Year & 1 & $411.45^{* *}$ & $299.68 * *$ & $99.06 * *$ & $762.26 * *$ \\
\hline Grass x Year & 13 & $8.39 * *$ & $5.77 * *$ & $2.59 *$ & $11.88^{* *}$ \\
\hline WL x Year & 5 & - & $\longrightarrow$ & $\longrightarrow$ & $24.42 * *$ \\
\hline Grass $x$ WL $x$ Year & 65 & $\longrightarrow$ & - & $\longrightarrow$ & $2.78 * *$ \\
\hline
\end{tabular}

$*, * *$ Significant at 0.05 and 0.01 probability levels, respectively

all other grassses at WL-5; however, Hycrest was in the higher tier of grasses for $\Delta$ at WL-5.

\section{Discussion}

Previous studies reported significant genetic variation for $\Delta$ in crested wheatgrass breeding populations, and the magnitude of the heritability estimates for $\Delta$ indicated that selection would be effective (Johnson et al. 1990, Read et al. 1993, Asay et al. 1998). Significant differences for $\Delta$ also were reported in orchardgrass, tall fescue, and perennial ryegrass, and the relative differences among species were consistent across irrigated and dryland conditions (Johnson and Bassett 1991). Asay et al. (1996) found significant differences for $\Delta$ among accessions and cultivars of Russian wildrye (Psathyrostachys juncea (Fisch.) Nevski). They also reported that tetraploid accessions made more efficient use of water than diploid cultivars. Frank et al. (1997) examined $\Delta$ in diploid and tetraploid crested wheatgrass and western wheatgrass (Pascopyrum smithii (Rydb.) A. Love) and reported that $\Delta$ was under genetic control and could likely be altered through breeding. In our study, significant differences also were observed for $\Delta$ among the 14 cool-season grasses we evaluated, particularly under the lowest water application. The range of mean $\Delta$ values found in our study (17-20.7\%o) fell within the range of $\Delta$ values $(16.1-23.1 \%$ o reported by Smedley et al. (1991) in their survey of a wide range of 42 species within a perennial grassland community near Salt Lake City, Utah.
Hycrest crested wheatgrass and Magnar Basin wildrye exhibited different $\Delta$ responses in our study. Hycrest grows well in areas that receive less than $250 \mathrm{~mm}$ of annual precipitation (Asay et al. 1985) and typically becomes dormant during the hot, summer period. Although Magnar Basin wildrye also grows in areas that receive low amounts of precipitation, it usually prefers ravines, swales, and areas with high water holding capacity that are favorable micro-environments. In our study, Hycrest consistently exhibited the highest $\Delta$ value (presumed lowest water-use efficiency) across water levels, whereas Magnar showed 1 of the lowest $\Delta$ values (presumed highest water-use efficiency). Initially, these responses seemed opposite from those expected. However, the higher values of $\Delta$ for Hycrest probably reflect its rapid, early vegetative growth in the spring compared to Magnar, which initiates growth later in the spring and produces much of its growth later in the summer than Hycrest. As a result, Hycrest probably has a high $\Delta$ because it produces most of its vegetative growth in the early spring when water is most available and stomatal limitations to water stress are minimal. In contrast, the low $\Delta$ values for Magnar probably reflect the prolonged activity of Magnar during more stressful conditions of the summer with greater stomatal limitation and subsequently lower $\Delta$ values than Hycrest. Smedley et al. (1991) reported similar trends where they found a seasonal decrease in $\Delta$ values that reflected prolonged plant activity during the stressful conditions of summer compared to early spring.
Another interesting response comparison in our study was between Hycrest and hexaploid crested wheatgrass. The slopes for dry matter yield were 0.34 for Hycrest and 0.35 for the hexaploid; however, the intercept values were markedly different. For example, Hycrest exhibited about a $2.5 \mathrm{Mg} \mathrm{ha}^{-1}$ greater dry matter yield than the hexaploid at WL-1; however, values of $\Delta$ were nearly the same for Hycrest and the hexaploid at WL- 1 . The similar $\Delta$ values at WL-1 suggest similar transpiration and gas exchange patterns for Hycrest and the hexaploid, but the dry matter yields are very different. Hexaploid crested wheatgrass has numerous, wide leaves compared to Hycrest so the hexaploid has a high leaf to stem ratio compared to Hycrest. Thus, part of the explanation in differential responses between these 2 crested wheatgrasses could be related to this difference in plant type, which was discussed by Brugnoli and Farquhar (2000).

Other factors that can influence responses in $\Delta$ include factors such as growth conditions, resistance between the intercellular spaces and sites of carboxylation, the effects of carbon losses during respiration and photorespiration, mineral nutrition of plants, and translocation of carbon among various plant parts (Farquhar et al. 1989). When the influence of these other components is substantial, the observed results for carbon isotope discrimination $(\Delta)$ can show a deviation from the expected response (Brugnoli and Farquhar 2000). As a result, although individual grasses may appear to differ in water-use efficiency based on differences in $\Delta$, these differences may reflect differences in other plant characteristics. For example, although Hycrest crested wheatgrass initiates growth early in the season and may produce considerable dry matter during this low stress period, Hycrest also may be able to extract soil water more effectively than the other grasses and, thereby, maintain a better water balance and produce greater dry matter yield at drier levels than the other grasses.

Dry matter yield is conditioned by many other genetic factors in addition to those associated with $\Delta$. In $C_{3}$ crop species, relationships between $\Delta$ and dry matter yield are sometimes positive and other times negative depending on the particular environmental conditions of the study (Brugnoli and Farquhar 2000). In early studies with clonal lines of crested wheatgrass, we found that $\Delta$ was positively correlated with dry matter yield, suggesting that selection for higher water-use effi- 
ciency would be accompanied by lower dry matter yield (Johnson et al. 1990). However, in later studies we found that dry matter yield was not correlated with $\Delta$ in crested wheatgrass breeding lines, indicating that genetic alteration of these 2 traits could be achieved concurrently (Read et al. 1992, 1993, Asay et al. 1998). Positive associations between $\Delta$ and dry matter yield probably would not be a major concern because dry matter yield is usually 1 of the primary selection criteria for evaluating breeding lines in most forage improvement programs. As a result, even though $\Delta$ may be positively related to dry matter yield in some situations, dry matter yield would be routinely evaluated and used as a primary selection factor in the breeding effort. Thus, $\Delta$ would most likely be used in a forage breeding program as 1 of several secondary selection criteria incorporated into a selection index.

In summary, we found that $\Delta$ decreased in a near linear manner from the wettest to driest water levels and that $\Delta$ varied significantly among the 14 perennial coolseason grasses that we evaluated, particularly at the lowest water level. We also found that dry matter yield decreased across water levels and differed significantly among the 14 grasses at the various water levels; however, the rate and manner of decline varied among grasses. In general, $\Delta$ was not closely associated with dry matter yield, suggesting that breeding efforts to improve these species should involve simultaneous selection for both dry matter yield and $\Delta$. Additional research is needed to clarify the complex interactions among $\Delta$, gas exchange, water relations, dry matter yield, and their interaction with environmental factors in these cool-season, perennial grasses.

\section{Literature Cited}

Asay, K.H. and D.A. Johnson. 1983. Breeding for drought resistance in range grasses. Iowa State J. Res. 57:441-455.

Asay, K.H., D.A. Johnson, and A.J. Palazzo. 1998. Parent-progeny relationships for carbon isotope discrimination and related characters in crested wheatgrass. Int. J. Plant Sci. 159:821-825.

Asay, K.H., D.R. Dewey, F.B. Gomm, D.A. Johnson, and J.R. Carlson. 1985. Registration of 'Hycrest' crested wheatgrass. Crop Sci. 25:368-369.

Asay, K.H., D. A. Johnson, K.B. Jensen, W.M. Sarraj, and D.H. Clark. 1996. Potential of new tetraploid germplasm in Russian wildrye. J. Range Manage. 49:439-442.
Brugnoli, E. and G.D. Farquhar. 2000. Photosynthetic fractionation of carbon isotopes, p. 399-434. In: R.C. Leegood, T.D. Sharkey, and S. von Caemmerer (eds.) Photosynthesis: physiology and metablolism. Advances in photosynthesis, Vol. 9. Clair Academic Publ., The Netherlands.

Condon, A.G., G.D. Farquhar, and R.A. Richards. 1990. Genotypic variation in carbon isotope discrimination and transpiration efficiency in wheat. Leaf gas exchange and whole plant studies. Aust. J. Plant Physiol. 17:9-22.

Farquhar, G.D. and R.A. Richards. 1984. Isotope composition of plant carbon correlates with water-use efficiency of wheat genotypes. Aust. J. Plant Physiol. 11:539-552.

Farquhar, G.D., J.R. Ehleringer, and K.T. Hubick. 1989. Carbon isotope discrimination and photosynthesis. Annu. Rev. Plant Physiol. Plant Mol. Biol. 40: 503-537.

Farquhar, G.D., M.H. O'Leary, and J.A. Berry. 1982. On the relationship between carbon isotope discrimination and the intercellular carbon dioxide concentration in leaves. Aust. J. Plant Physiol. 9: 121-147.

Frank, A.B., I.M. Ray, J.D. Berdahl, and J.F. Karn. 1997. Carbon isotope discrimination, ash, and canopy temperature in three wheatgrass species. Crop Sci. 37:1573-1576.

Gomez, K. A. and A. A. Gomez. 1984. Statistical procedures for agricultural research, p. 230. $2^{\text {nd }}$ ed. John Wiley \& Sons, New York.

Hall, E., R.A. Richards, A.G. Condon, G.C. Wright, and G.D. Farquhar. 1994. Carbon isotope discrimination and plant breeding. Plant Breeding Reviews 12:81-113.

Johnson, D.A. and K.H. Asay. 1993. Viewpoint: Selection for improved drought response in cool-season grasses. J. Range Manage. 46:194-202.

Johnson, D.A., K.H. Asay, L.L. Tieszen, J.R. Ehleringer, and P.G. Jefferson. 1990. Carbon isotope discrimination: Potential in screening cool-season grasses for water-limited environments. Crop Sci. 30:338-343.

Johnson, R.C. and L.M. Bassett. 1991. Carbon isotope discrimination and water use efficiency in four cool-season grasses. Crop Sci. 31:157-162

Mook, W. G., M. Koopmans, A.F. Carter, and C.D. Keeling. 1983. Seasonal, latitudinal, and secular variations in the abundance of isotopic ratios of atmospheric carbon dioxide: I. Results from land stations. J. Geophys. Res. 88:10915-10933.

Read, J.J., K.H. Asay, and D.A. Johnson. 1993. Divergent selection for carbon isotope discrimination in crested wheatgrass. Can. J. Plant Sci. 73:1027-1035.

Read, J.J., D.A. Johnson, K.H. Asay, and L.L. Tieszen. 1991. Carbon isotope discrimination, gas exchange, and water-use efficiency in crested wheatgrass clones. Crop Sci. 31:1203-1208.
Read, J.J., D.A. Johnson, K.H. Asay, and L.L. Tieszen. 1992. Carbon isotope discrimination: Relationship to yield, gas exchange, and water-use efficiency in field-grown crested wheatgrass. Crop Sci. 32:168-175.

SAS Institute Inc. 1999. SAS/STAT user's guide. Ver. 8, SAS Institute Inc., Cary, N.C.

Smedley, M.P., T.E. Dawson, J.P. Comstock, L.A. Donovan, D.E. Sherrill, C.S. Cook, and J.R. Ehleringer. 1991. Seasonal carbon isotope discrimination in a grassland community. Oecologia 85:314-320.

Upchurch, D.R., J.T. Ritchie, and M.A. Foale. 1983. Design of a large dual-structure rainout shelter for use in excluding rainfall from crops in water stress studies. Agron. J. 75: $845-848$. 